\title{
Operation Mechanism Research of Outstanding Engineer Industry
}

\author{
Academy Cooperation
}

\author{
Yinxia Wei \\ Xiamen University \\ Xiamen, China \\ Guilin University of Electronic Technology \\ Guilin, China
}

\begin{abstract}
Outstanding engineers mainly adopt industry and academy cooperative education as well as the two educational environments of schools and enterprises to arrange undergraduates' course learning and social practice, Outstanding engineer makes the talent training cases, the teaching content and the practical circles closer to the demand of social development, promotes innovation, practical capacity and engineering quality of students, and then cultivates excellent engineering and technological talents. By applying Excellent Engineer Training Program, Guilin University of Electronic Technology eventually shapes a set of industry and academy cooperation mechanism which is suitable to the qualities of different majors and different types of enterprises as well as the organizational connection system which can secure the long-term steady cooperation between school and enterprise. In this way can they achieve the goal to cultivate engineering talents together?
\end{abstract}

Keywords-outstanding engineer; industry and academy cooperation; operation mechanism

\section{INTRODUCTION}

"Outstanding Engineer Cultivation Plan" is the important reform program to carry out "National Medium and LongTerm Planning outline for Education Reform and Development (2010-2020)" and "Outline of National Medium and Long-term Talent Development Program (2010-2020)", it is also the big measure for China to promote the transfer from a big engineer education country to a powerful engineer education country. Ever since 2010, colleges in China carry out pilot of Outstanding plan, nowadays, there are more than 200 colleges getting involved in it. The three main features of it are as follows: the first character are those enterprises in-depth getting involved in the cultivation process; the second character is that colleges cultivate engineer talents according to the common standard and business standard; the third character is to strengthen the students' engineering capacity and innovative capacity. Most of colleges take $3+1$ mode to cultivate their students, which is to cultivate students in the enterprises for one year to practice their practical abilities and cultivate the reserved talents of engineers. In fact, Outstanding engineer is divided into two cultivating systems: campus cultivation and society cultivation. Society cultivation system basically depends on industries and enterprises to develop industry and academy cooperative education; it is the most important characteristic and also the nature of Outstanding engineer education. In 2011, Guilin University of Electronic Technology is ratified as Outstanding engineer Application College, up to now, there are six majors that apply Outstanding plan and it has made some experience in aspect of industry and academy cooperation.

\section{INTEREST AND POWER CONSTRAINT OF EACH PARTY IN THE STAGE OF COMPANY INTERNSHIP}

\section{A. Interest Relevant Parties in the Stage of Company Internship}

Operational mechanism means that in the regular movement of humanistic society, the structures, functions and their mutual relations of the factors that affect the movement as well as the producing elements, the influential process and principles and operational ways of these factors. Operational mechanism is the mutual relations and their influences as well as their restraint relations of various elements in the operation process, among which the most important one is the interest relation. The most important thing for Outstanding engineer industry and academy cooperation is the establishment of industry and academy cooperative operational mechanism and to coordinate the interest relations of each party, to get the best mode of the cooperation of engineer and practice education through system courage and restrain. The interest relevant parties involved in Outstanding engineer education are: government, colleges, enterprises and students, the input and interest of them in engineer education are different. "Table I" 


\begin{tabular}{|c|c|c|}
\hline Parties & Input & Interest \\
\hline $\begin{array}{l}\text { Govern } \\
\text { ment }\end{array}$ & $\begin{array}{l}\text { Educational fund, educational strategies, } \\
\text { industrial plan, carder and so on }\end{array}$ & $\begin{array}{l}\text { Employment of undergraduates; social security/stability; regional } \\
\text { economic and industrial development; establishment of innovative } \\
\text { country, industry upgrade }\end{array}$ \\
\hline $\begin{array}{l}\text { Enterpr } \\
\text { ises }\end{array}$ & $\begin{array}{l}\text { Internship and study opportunities of } \\
\text { undergraduates; offer vocational environment; } \\
\text { enterprise expert advisers; undergraduate } \\
\text { management }\end{array}$ & $\begin{array}{l}\text { Choose undergraduates appropriate to job positions; entrepreneurship } \\
\text { honor; social responsibility; technique development; promoting of } \\
\text { staffs' degree }\end{array}$ \\
\hline $\begin{array}{l}\text { Colleg } \\
\text { es }\end{array}$ & $\begin{array}{l}\text { Teachers, management, educational environment } \\
\text { furniture }\end{array}$ & $\begin{array}{l}\text { Training of teachers; horizontal subjects; cultivation of students' } \\
\text { career; social honor of colleges; expansion of educational resources and } \\
\text { so on }\end{array}$ \\
\hline $\begin{array}{l}\text { Student } \\
\mathrm{S}\end{array}$ & Studying expense, time & $\begin{array}{l}\text { Cultivation of knowledge, quality, capacity; acquiring real engineering } \\
\text { practice environment; vocational development }\end{array}$ \\
\hline Parties & Input & Interest \\
\hline $\begin{array}{l}\text { Govern } \\
\text { ment }\end{array}$ & $\begin{array}{l}\text { Educational fund, educational strategies, } \\
\text { industrial plan, carder and so on }\end{array}$ & $\begin{array}{l}\text { Employment of undergraduates; social security/stability; regional } \\
\text { economic and industrial development; establishment of innovative } \\
\text { country, industry upgrade }\end{array}$ \\
\hline $\begin{array}{l}\text { Enterpr } \\
\text { ises }\end{array}$ & $\begin{array}{l}\text { Internship and study opportunities of } \\
\text { undergraduates; offer vocational environment; } \\
\text { enterprise expert advisers; undergraduate } \\
\text { management }\end{array}$ & $\begin{array}{l}\text { Choose undergraduates appropriate to job positions; entrepreneurship } \\
\text { honor; social responsibility; technique development; promoting of } \\
\text { staffs' degree }\end{array}$ \\
\hline $\begin{array}{l}\text { Colleg } \\
\text { es }\end{array}$ & $\begin{array}{l}\text { Teachers, management, educational environment } \\
\text { furniture }\end{array}$ & $\begin{array}{l}\text { Training of teachers; horizontal subjects; cultivation of students' } \\
\text { career; social honor of colleges; expansion of educational resources and } \\
\text { so on }\end{array}$ \\
\hline $\begin{array}{l}\text { Student } \\
\mathrm{S}\end{array}$ & Studying expense, time & $\begin{array}{l}\text { Cultivation of knowledge, quality, capacity; acquiring real engineering } \\
\text { practice environment; vocational development }\end{array}$ \\
\hline
\end{tabular}

Each interest related party has its own thinking on interest. The key of industry and academy education is to insist the principle of equality and mutual-benefits, when designing school and enterprise cooperation cases, both parties should find out the coherence point of the interest of school and enterprise to promote the enthusiasm of their cooperation, and establish long-term operational system that can achieve mutual benefits through cooperation to realize the deep coherence of them. As long as the colleges are sincere and put themselves in others' shoes, understand and support the demand of enterprises and find out the interest requirements of some relevant enterprises, then cooperation will be a matter of course, therefore, they can achieve their cooperative goal--to advance the quality of talents.

\section{B. Make Triple Agreement and Realize Interest Restraint}

Nowadays, the interest restraint among colleges, enterprises and students is mainly realized through school and enterprise cooperation. Triple agreement (some colleges sign mutual agreement) is the basic institutional file of school and enterprise cooperation. The main contents include the purpose, content, mutual rights, responsibilities, and consequences of disobeying the rule of the triple cooperation among colleges, enterprises and students. This agreement has its legal force and characteristic of mandatory constraints in nature, all the three parties should obey it. Before the students in Outstanding plan major of Guilin University of Electronic Technology go to internship, all of colleges, enterprises and students must sign an agreement. The agreement regulates the responsibility o f enterprises: get involved in the making of professional training cases, take charge of the course setting, teaching instruction, teaching management and specific applications and so on in the stage of enterprise internship. The agreement highlights the interest of students: they must take part in the analysis, design, production, inspection and management of enterprise engineering project, enterprises should cultivate students' abilities of analyzing and solving problems as well as team work capacity. In fact, the triple agreement restrains the profit elements institutionally in the operation of school and enterprise cooperation. The managing mode of enterprises as the managing body, the students self-management and the colleges getting involved in the whole process has been formed via making triple agreement among schools, enterprises and students is formed.

\section{EDUCATIONAL SECURITY SYSTEM OF INDUSTRY AND ACADEMY COOPERATION}

\section{A. Set School and Enterprise Cooperation Institute and Gives It Functions}

It is the efficient insurance of the successful operation of industry and academy to establish efficient organizational and leading system. Colleges found comprehensive reform and leading group to cultivate talents, which takes charge of the whole plan and makes regulations, and Outstanding plan office subordinates to the dean's office, which takes charge of the promotion of the specific businesses of Outstanding plan. They identify a group of enterprises with good cooperative relations and with high popularity to establish engineer practice education center as the practice foundation of Outstanding plan. In addition, they set a professor committee, which consists of teachers at school and engineering professors in enterprises, they take charge of checking the cultivation cases and central developing plan of engineer practice education, arranging students' internship and enterprises' practical course system. They build engineer practice education office in enterprises to take charge of the undergraduates' teaching management work, which includes archive management, security management, secure system, work- ing regulations, operation regulations and so on, during their internship in enterprises. The center makes 
the cultivation standard and testing requirement with the colleges and judges the cultivation quality of the undergraduates' work in the internship period.

\section{B. Establish Double Supervisor Team to Make Sure of the Cultivation Quality}

According to Outstanding's requirements to teachers, they shape a high level teaching team which combines professional teachers at colleges and part-time teachers in enterprises. On one hand, the current professional teachers are supported and encouraged to enterprises to gain enough engineering practice experience via efficient humane system and policy. The temporary working period of teachers in enterprises is accounted into their annual evaluation, teachers are paid the entire performance pay and position fund and reimbursed their back and forth trip fee. Based on various engineering research center, the personnel of both sides develop industry and academy cooperation.Outstanding plan carries out double supervisor system for students, which means that there are academic supervisors in colleges, while there are enterprising supervisors in enterprises. Under the supervision of teachers, students get involved in the development and design of enterprises through participating in projects to advance their engineer quality and increase the function of enterprise to skill service.

\section{School Platform, Professional Expense Support}

Guilin University of Electronic Technology established Innovation College in Guangxi in 2013. Innovation college is the practical education base of cultivating Outstanding engineer talents in campus,where Outstanding engineer working shop which includes four majors of communication, mechanism, measurement, control and software has been established.Beside, there are electronic design innovation room , automatic control and application innovation room, mechanism innovation design room, innovation training room and so on in innovation college. A systemic and comprehensive practice platform has been formed. The innovation college realizes the cross-major coordinate practice through engineer projects, making the students of Outstanding plan have real engineering environment in the process of their practical education in campus and the atmosphere become much closer to the enterprises. The university and enterprise have established two national engineering practice education centers and one college students' practical education based out of campus, and more than 20 school engineering practice education centers.

The university establishes Outstanding plan professional expense that supports the establishment of Outstanding plan professional labs, the educational reform, the educational researches, school and enterprise cooperation, student's management, the construction of teachers' team, the internship base and so on. Outstanding courses account its amount of teaching work according to 1.5 times as the common classes. In addition, each major spends 300,000 Yuan professional expense each year in the opening of enterprising courses, the wage of the supervisors' classes and the insurance fee and so on; each student is paid 2,000 Yuan for their internship.

\section{EDUCATION MANAGEMENT SYSTEMS OF OUTSTANDING ENGINEER INDUSTRY AND ACADEMY COOPERATION EDUCATION}

Engineer education must comes back to engineer facts, the cultivation of engineer talents must face the enterprises actuality, the cultivation goal and specific cultivation method must meets the demand of enterprises. On the perspective of management normalized construction, a highly efficient construction, operation and management system for the outcampus engineer practice education center has been established.

\section{A. Collaborated Enterprise Cultivation Case by School and Enterprise}

Enterprise cultivation case is the blueprint for students to realize their engineer practical ability and vocational virtue; it is the plan of students' knowledge, quality and ability realization. Different to higher vocational education, students who enter into enterprises should not only work, but also change their positions, what's more, there are complete training courses and study arrangement. Guilin University of Electronic Technology has six professional majors that carry out Outstanding plan at the moment. The university explores national standard and industrial standard and makes the standard to cultivate talents' quality. And it discusses with cooperative enterprise about each major through several drafts to finally complete the cultivation case and subject system of "Outstanding plan" of some majors such as communication project, computer and science and technique and so on.

\section{B. Detailed Student Management System}

The pilot class makes the tutor, head teacher and supervisor triple management mode. The tutor and head-teacher take charge of the thoughts education and daily management work, while the learning supervisor and enterprise supervisor take charge of the students' study in campus and enterprises. Each Outstanding plan class has been equipped with a professional tutor, a head-teacher and every six students are equipped with a learning supervisor. The learning supervisor takes charge of the students' professional education and the make of individualized study cases, and provides students with constructs and consults about the specific research project or engineer practice project.At the end of their third grade, when student enters into the enterprise for internship, each student is provided with enterprise supervisor which are responsible for the students in enterprise stage and the practice and instruction work. Under the construction of double supervisor, combing the subject, they get involved in the enterprise technology innovation and engineer project development, and complete their graduation design on this basis. The department office and dean's office take charge of the students' registration and administration management work. In addition to obtain the common graduate certificate, the graduates can also achieve relevant Outstanding plan professional certificate. Before entering enterprises to study, colleges buy insurances for each student. During their internship in engineer practice education center, students is managed according to the regulations and rules of enterprises, College Students Leave and Terminate 
Leave System is established, and the capacity to get accustomed to the culture of the enterprise is paid attention.

\section{School and Enterprise Collaborated Development of Courses, Complication of Teaching Materials}

The experimental courses of Outstanding plan are advanced subjects that have close relations with industry; they have good school and enterprise cooperation basis in talent cultivation, team construction, platform construction, project development and skill cooperation and so on. They complicate Outstanding plan teaching materials together and open up subjects. Colleges employ leading characters and technological elites in enterprise to give lectures to the students.Nearly three years, they hold a list of Outstanding engineer lectures, and it is the vivid and specific lectures of the successful people to make the students have more comprehensive knowledge about how to become good Outstanding engineers. Through the school and enterprise cooperative development, they combine the professional teaching content with the fact of enterprise engineer. In the 2012 undergraduate talents cultivation case, they set moving enterprise courses to realize its connection to the market. For instance, there are two enterprise directors teach the "C/C++ course design" and "Java course design" courses in computer and science and technique majors. In order to follow the developing trend of each industry, each Outstanding plan major cooperates with its subordinate enterprises to complicate teaching materials, making sure of the frontier quality and accustomed quality of the major knowledge. Each Outstanding plan major complicates more than two teaching materials with enterprises and industries.

\section{School and Enterprise Collaborated to Construct the Graduate Design}

The graduate design of Outstanding plan originates from enterprises absolutely. Under the producing management system and operation mode of enterprises, students should complete development of one or two real projects that should be outstanding industrial characteristic and take innovation as goal to promote students' professional techniques and project experience. The subject of the graduate design of Outstanding classes should extrude the designing quality and comprehensive quality to focus on the cultivation of the engineer consciousness, independent scientific research capacity, cooperative and coordinate spirit of students, and their innovative consciousness and capacity. In the entire process of the graduate design of enterprises, both of school supervisors and enterprise supervisors should get involved in the instruction of the students' graduate design, checking and thesis defense. For instance, Guilin Medical Mechanic Company endows the internship students 1000,000 Yuan per year in the development of project, people who succeed in developing can go into the production circle of products. All the graduate design of students is the contents of product development. Under the instruction of enterprise supervisor, students get involved in the development and design work of the enterprise, which can help them promote their engineer quality and increase the enterprise' s outside technical service function.

\section{E. Establishment of School and Enterprise Co-Management Quality Management System}

School and enterprise make the cultivation standard and testy requirement of the enterprise studying stage and judgment together about the cultivation quality of students in the enterprise study stage, and set up a set of assessments and test systems of scientific and appropriate engineer education practice effect. They carry out Outstanding plan enterprise internship on-duty management method,and make referring file ,such as "Student Internship Brochure of Guilin University of Electronic Technology Outstanding Engineer Cultivation Plan", to set relevant regulations on each teaching circle such as studying report and assessment of enterprise security education and enterprise culture learning, grade assessment of enterprise engineer practice, enterprise internship report, undergraduate graduate design (thesis) mark sheet, enterprise project design mark sheet, enterprise study weekly model, enterprise graduate certificate and so on.

Based on the above analysis, Guilin University of Electronic Technology gropes in practice, reforms and innovates the engineer talent training mode of our college, satisfies the interest demand of enterprises, promotes the deep coherence between school and enterprise use talents, establishes a set of cooperation operation management mode which is suitable to different major qualities and enterprise types, shapes a management mode of enterprise as the body of management, students self-management and colleges getting involved in the entire process of management and makes industry and academy cooperation operates steadily in a long term.

\section{REFERENCES}

[1] Zhu Xiumin. Construction of Co-management System of School and Enterprise Education under the Mode of Outstanding Engineer Education and Cultivation Plan. Modern Education Management, 2013 (6)

[2] Cha Jianzhong. "Macro Control Model and Cultivate Goal and Education Assessment of Engineer Education" [J]. Higher Engineering Education Research, 2009 (3). 